\title{
Can facet joint infiltrative analgesia reduce postoperative pain in degenerative lumbar disc surgery?
}

\author{
G. Bademci; H. Basar***; S. Sahin*; S. Ozcakir*; H. Anbarci; C. Evliyaoglu and S. Keskil**
}

Departments of Neurosurgery and Anesthesiology and Reanimation*. Faculty of Medicine. University of Kirikkale. Kirikkale. Turkey. Department of Neurosurgery**. Bayindir Medical Center. Ankara, Turkey. Department of Anesthesiology and Reanimation***. Ankara Hospital. Ankara, Turkey.

Summary

Objective. Perioperative analgesia effects the postoperative course of pain. The purpose of this study was to evaluate its possible relation with the consumption of dolantine and analgesics and the facet-induced pain and postoperative pain score in degenerative disc surgery.

Methods. We employed perioperative intra- and perifacet bupivacaine infiltration technique to reduce the postoperative pain after lumbar disc surgery. The study was randomized and observer blinded enrolling 40 American Society of Anesthesiologists physical status class I-II patients scheduled for elective degenerative lumbar disc surgery. The patients were divided into two groups of 20 of which Group 1 underwent injection of bupivacaine into the subcutaneous and muscular layers around the incision site, while Group 2 underwent additional intra- and perifacetal joint infiltration. Postoperatively, the patients were provided with a programmed patient-controlled pump which was only activated on demand to infuse dolantine for the next 24 hours. In the postanesthesia care unit the delay for analgesia and the dose of dolantine used were recorded.

Results. There was no statistical significance between these two groups regarding postoperative visual analoque scale scores. The time before the first analgesic request was significantly longer in facet group $(p=$ $0,006)$. The cumulative dolantine dose was also significantly lower in the facet group $(p=0,001)$

Conclusion. The results indicate that facet joint infiltrative analgesia may have an effect on the postoperative analgesic requirement and reduce the dolantine consumption.

KEY WORDS: Analgesia. Facet joint infiltration. Discopathy. Lumbar surgery.

¿Puede reducirse el dolor postoperatorio en la cirugía discal degenerativa lumbar con infiltración de analgésicos?

Recibido; 24-11-06. Aceptado: 12-02-07
Resumen

Objetivo. La analgesia peroperatoria influye en el curso del dolor postquirúrgico. El propósito del estudio reside en la evaluación de la posible relación entre el consumo de dolantina y otros analgésicos en el control del dolor postquirúrgico de origen facetario lumbar en la enfermedad discal degenerativa.

Métodos. Empleamos peroperatoriamente infiltraciones percutáneas de bupivacaína intra y perifacetaria para reducir el dolor postoperartorio tras cirugía discal lumbar. El estudio fue randomizado y oculto al observador y se realizó sobre $\mathbf{4 0}$ pacientes operados de cirugía electiva por enfermedad degenerativa lumbar, con una situación general Clase I-II de la clasificación de la American Society of Anesthesiologist. Los pacientes se dividieron en dos grupos de 20 .El Grupo 1 se le administró bupivacaína en el tejido subcutáneo y capas musculares. El grupo 2 recibió una inyección adicional de bupivacaína intra y perifacetaria. Durante el postoperatorio, los pacientes, dispusieron de una bomba programable de analgesia controlada, que se activó exclusivamente a demanda para infundir dolantina en las $\mathbf{2 4}$ horas siguientes a la operación. En la Unidad de Reanimación postquirúrgicas se recogieron las necesidades de dolantina de los distintos pacientes.

Resultados. No se encontraron diferencias estadísticamente significativas entre ambos grupos en relación a los valores de la escala analógica visual. El tiempo de demanda del primer bolo analgésico fue significativamente mayor en el grupo de facetas infiltradas $(p=0,006)$. La acumulación de las dosis de dolantina fue también significativamente inferior en el grupo de facetas infiltradas $(p=0.001)$.

Conclusión. Los resultados indican que la infiltra-

Abbreviations. ASA:American Society of Anesthesiologists. NSAID: non steroidal antiinflamationy drugs. PACU: post-anesthesia care unit. PCA: patient-controlled anesthesia. SD: standard deviation. VAS: visual analogue scale. 
ción de la faceta articular con anestésico local puede tener un efecto positivo reduciendo las necesidades analgésicas postoperatorias de dolantina.

PALABRAS CLAVE: Analgesia. Infiltración facetaria. Disco lumbar. Cirugía lumbar.

\section{Introduction}

Postoperative pain is the most undesirable experience for surgical patients. Several authors have found that perioperative infiltration of steroids and local anesthetic agents into the different wound sites reduces postoperative pain $^{3,5,6,7}$. In degenerative lumbar disc surgery the pain may originate from various sources such as skin, muscles, vertebrae, anulus fibrosis and facet joints. Facet joints are covered by a very rich nerve plexus ${ }^{4}$. During disc degeneration, facets are affected by pathologic processes resulting in facet-induced pain. If the pain caused by facet joint degeneration is not prevented, postoperative pain management may be prolonged and threatened.

This study aims to determine the efficacy of intraand perifacetal local anesthetic agent infiltration on postoperative pain relief after degenerative lumbar disc surgery.

\section{Patients and Method}

After approval of Instutional Human Ethics Committee and obtaining written informed consent, 40 patients aged between 25-60 were included in a prospective and observer blinded study. Patients were selected among consecutive patients who did not present with any of the exclusion criteria admitted to the University of Kirikkale, Faculty of Medicine from January 2002 to September 2005 and scheduled for uni-level lumbar disc surgery after preoperative and postoperative diagnosis of degenerative herniated lumbar disc. All patients had American Society of Anesthesiologists (ASA) physical status class I-II. Study exclusion criteria were: ASA physical status class III, IV or V; history of chronic pain, regular use of analgesics or use of opioids within $12 \mathrm{~h}$ before surgery; chronic use of benzodiazepine or clonidine, history of drug or alcohol abuse; history of allergy to opioids or any other drug used in the study; contraindications to the self-administration of opioid (i.e. inability to understand the patient-controlled analgesia (PCA) system), psychiatric disorders; pregnancy, presence of hepatic, kidney or pulmonary dysfunction, and other lumbar pathologies. The duration of low back pain before operation was ranged between 7- 89 months. All the patients suffered from low-back pain in variable intensity. Additionally, 15 of patients were traced the distribution of pain along the leg. All of the patients used adequate pain medication before surgery. The diagnosis was confirmed with lumbar MRI.

Every patient was premedicated with $2 \mathrm{mg}$ midazolam intravenously 15 minutes before the operation. The patients were monitorized for heart rate; peripheral oxygen saturation; systolic, diastolic and mean arterial pressures. General anesthesia was induced with fentanyl $1 \mu / \mathrm{kg}$, propofol $2 \mathrm{mg} / \mathrm{kg}$ and vercuronium $0.1 \mathrm{mg} / \mathrm{kg}$. Classical microsurgical lumbar disc surgery was performed. Patients were assigned randomly into two groups: At the end of the operation, the patients in Group 1 (control group) were administered $15 \mathrm{~mL} 0.25 \%$ bupivacaine infiltration through the dermis, hypodermis and muscular layers while in Group 2 (intra- and perifacetal injection group), identical analgesia was applied as in Group 1 with the only difference being an additional intra- and perifacetal infiltration. The facet joint and perifacetal tissue was infiltrated with $1.5 \mathrm{~mL} 0.25 \%$ bupivacaine. The main parameter for the success or failure of this treatment was the reduced pain compared with the control group. All the patients were followed postoperatively in the post-anesthesia care unit (PACU) with a programmed patient-controlled anesthesia (PCA) pump which was only activated on demand. Dolantine was used to treat pain in doses of $10 \mathrm{mg}$ for the first sense of pain; and $20 \mathrm{mg}$ for the bolus infusion (PCA pump was set on 10-min lockout). Haemodynamic data, ventilatory frequency, first conception time of the pain; $\mathrm{SpO}_{2}$, visual analogue scale (VAS) scores ( $0=$ absence of pain; $10=$ unbearable pain) preoperative and at the $1^{\text {st }}, 2^{\text {nd }}, 4^{\text {th }}$, $6^{\text {th }}, 12^{\text {th }}$, and $24^{\text {th }}$ postoperative hours, and VAS scores basal and evoked with pressure to the incision, total dose of dolantine required, delay for analgesia, need for additional analgesics and quality of relief of pain assessed using a questionnaire as insufficient, good or excellent at the 24th hour were recorded and compared between the groups. Data were presented as mean \pm Standard Deviation (SD) or median with interquartile range. Statistical analysis was performed using Student's t-test for comparison between two groups' variables and Repeated Measurements Analysis of Variance for comparison of continuous variables. The significance threshold for the tests was set at $\mathrm{p}<0,05$.

\section{Results}

None of the patients was excluded due to either misunderstanding the use of PCA or technical failure. Patient characteristics and duration of anesthesia were similar in the two groups (Table 1). Preoperative median VAS scores were $8 \pm 3.2$ for Group 1 and $8.3 \pm 1.4$ for Group 2. 
Table 1

Patient characteristics

\begin{tabular}{|l|c|c|}
\hline & Group 1 & Group 2 \\
\hline Age (year) & $41,4 \pm 8.0$ & $40,8 \pm 7,6$ \\
\hline Weight (kg) & $74,30 \pm 13,5$ & $79,3 \pm 9,4$ \\
\hline Height (cm) & $165,3 \pm 7 \quad 169 \pm 9$ \\
\hline Sex (M/F) & $13 / 7$ & $8 / 12$ \\
\hline $\begin{array}{l}\text { Duration of } \\
\text { anesthesia (min) }\end{array}$ & $160 \pm 37$ & $169 \pm 34$ \\
\hline
\end{tabular}

There was no statistical significance between these two groups regarding postoperative VAS scores both at resting and evoked pain (Figure 1). In Group 1 VAS values were noted to be at the $1^{\text {st }}$ hour $4.7 \pm 2.1,2^{\text {nd }}$ hour $3.5 \pm 2,4^{\text {th }}$ hour $2.8 \pm 2.1,6^{\text {th }}$ hour $5 \pm 1.4,12^{\text {th }}$ hour $1.5 \pm 1.2,24^{\text {th }}$ hour $0.9 \pm 1.8$ and in Group 2; 4.05 $\pm 2,2.5 \pm 2.1,2.2 \pm 2.1,1.8 \pm 2,1 \pm 1.4$ and $0.55 \pm 0.9$, respectively. In Group 1 , pressure VAS values were $1^{\text {st }}$ hour $6.2 \pm 2.1,2^{\text {nd }}$ hour $5.1 \pm 2.2,4^{\text {th }}$ hour $4.3 \pm 2.3,6^{\text {th }}$ hour 3.6 $\pm 2,12^{\text {th }}$ hour $3 \pm 1.7,24^{\text {th }}$ hour $1.9 \pm 1.8$ and in Group 2; $5.7 \pm 1.9$, 4.8 \pm 2 , $4.1 \pm 2,3.9 \pm 1.9,2.9 \pm 1.6$ and $2.2 \pm 1.4$, respectively (Figure 1).

Total dolantine requirement during the study was significantly lower in Group 2 (Group $1=163.9 \pm 23 \mathrm{mg}$, Group $2=132.7 \pm 30,3 \mathrm{mg}, \mathrm{p}=0.001)$ while the additional anal- gesic request in the PACU was significantly lower in the Group 2 ( Group $2=27.2 \pm 9,17 \mathrm{mg}$, Group $1=58,05 \pm 46,85$ $\mathrm{mg}, \mathrm{p}=0.006$ ). The time before the first analgesic request was significantly longer in Group $2(p=0,006)$. The length of hospitalization was lower in the Group 2 (Group $1=4 \pm 1$ / day; Group 2=2 \pm 1 /day).

\section{Discussion}

This prospective, randomized study confirmed our hypothesis that perioperative facet joint infiltrative analgesia is effective in the management of postoperative pain after degenerative lumbar disc surgery. Consequently, the first analgesic administration time was delayed in Group 2. The cumulative PCA dolantine use over the first $24 \mathrm{~h}$ was less in the intra- and perifacetal injection group. Pain relief appears to be rapid and prolonged at the end of surgery, because bupivacaine is a long-acting local anesthetic agent and its pharmacokinetic characteristics explain the residual analgesia that exists long after its usage.

In fact, facet joint block is described as a percutaneous minimally invasive procedure used to differantiate between facet joint pain and other causes of lower back pain $^{1,2}$. However, the role of facet blocks in differential diagnosis is very controversial and based on no strong evidence. We modified this technique as a perioperative degenerative lumbar disk surgery procedure. We propose that the procedure may also be useful for distinguishing between facet joint pain due to intraoperative manipula-

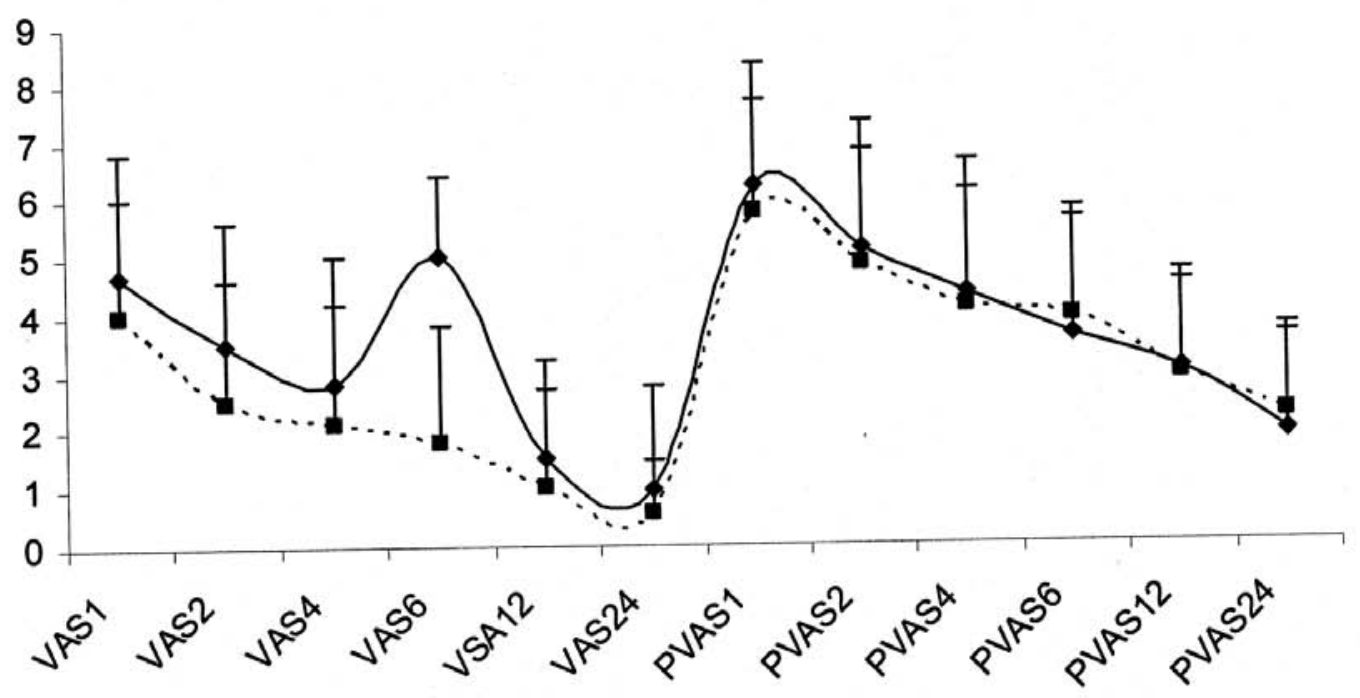

Periods



Figure 1. Graphic displaying VAS and pressureVAS (PVAS) scores. 
tions and postoperative pain due to inappropriate neural decompression.

Effectiveness of lumbar disc surgery has been reported to be in a ratio varying between 10 to $60 \%{ }^{10}$. The acute pain due to direct nociceptor activation is usually gone within hours after surgery; but sometimes pain may last much longer -days, weeks, months. This subacute pain is not a direct result of the initial impact but a later development, reflecting a series of changes both in the peripheral tissue and in the associated spinal cord segments. NSAIDs and opioids can treat acute pain on their ability to inhibit the generation of hyperalgesic mediators in injured tissue; but they are not helpful when subacute pain has already developed. If precautions were taken to prevent initiation of the central mechanism, postoperative pain might be greatly diminished. The idea, "preventive analgesia", is to prevent the induction of central mechanism after the surgery in the first place by blocking the initiation and arrival of intense nociceptive input to the spinal cord resulting in less amplification of afferent signals and less pain.

Successful studies have encouraged the idea that preventing analgesia might be useful. Most of the studies compared postoperative pain in patients who underwent operation with or without the usage of a pain preventing strategy ${ }^{3,5,6,7}$. Although the present literature contributes to our knowledge of postoperative pain relief provided by different preoperative and intraoperative analgesic techniques, up to our knowledge there is no study of intraoperative intra- and perifacet joint infiltration aimed for the facet-induced pain. It was previously reported that during lumbar surgery under general anesthesia, infiltration of the wound with local anesthetics reduces the postoperative pain and postoperative usage of analgesics ${ }^{3,5,7}$. However, subacute pain also includes pain resulting from the lomber articulating facets. Facets are a kind of zygomaticoapophyseal joints and affected by the degenerating processes associated with lumbar discopathy. And it is known that lumbar pain may be persistent after disc operations that are successfully performed, since degenerated facets may trigger subacute pain and muscular spasm.

The facet joints have a very rich innervation network. Root is splitted into an anterior and a posterior ramus after exiting the intervertebral foramen. Posterior ramus traverses posteriorly beyond the intertransverse ligament and gives an articular branch (posterior articular nerve of Luschka). This branch innervates the lateral and caudal faces of the facet capsule ${ }^{4}$. In degenerative discopathies such as chronic disc diseases; degenerative spondylolisthesis; the alignment and connections of the articular facets are affected resulting in irritation of the sensory nerves. Rees claimed that persistent postoperative pain might be treated by sectioning the Luschka nerve ${ }^{8}$ and Shealy described the facet denervation procedure by radiofrequency ${ }^{9}$. Percuta- neous facet denervation is a widely used method in articular facet syndrome, applied if local anesthetic infiltration of the facet can relieve pain.

Our technique may also be helpful as a diagnostic test method since the patient can be also recommended to undergo percutaneous facet denervation as a postoperative midterm follow-up intervention for persistent low back pain.

The described technique provides both a reduction in sedative and analgesic doses which may induce a feeling of illness during the early postoperative period and a socioeconomical benefit by reducing the length of postoperative hospitalization. We conclude that intraoperative infra- and perifacetal infiltrative analgesia technique prevents the central sensitization triggered by degenerative facet joints and may play a major role against postoperative pain or the transition from acute to subacute pain.

\section{Conclusion}

The technique may contribute to the feeling of wellbeing by reducing pain; a benefit attributable to preemptive analgesia. The effect of the preemptive analgesic treatment on the long-term pain perception of the patients may be consider as a concern of different study with a longer follow-up.

\section{References}

1. Bani, A., Spetzger, U., Gilsbach, J.M.: Indications for and benefits of lumbar facet joint block: analysis of 230 consecutive patients. Neurosurg Focus 2002; 15; 13: E 11.

2. Giles, L.G.: Low back facet joint anesthesia. Spine 1999; 24: 1388-1390.

3. Jebeles, J.A., Reilly, J.S., Gutierrez, J.F.: The effect of preincisional infiltration of tonsils with bupivacaine on the pain following tonsillectomy under general anaesthesia. Pain 1991; 47: 305-308.

4. Lau, P., Mercer, S., Govind, J., Bogduk, N.: The surgical anatomy of lumbar medial branch neurotomy (facet denervation). Pain Med 2004; 5: 289-298.

5. Lohsiriwat, V., Lert-akyamanee, N., Rushatamukayanunt, W.: Efficacy of pre- incisional bupivacaine infiltration on postoperative pain relief after appendectomy: prospective double-blind randomized trial. World J Surg 2004; 28: 947950.

6. Niv, D., Devor, M.: Pre-emptive analgesia in the relief of postoperative pain. Curr Rev Pain 1996; 1: 79-92.

7. Patel, J.M., Lanzafama, R.J., Williams, J.S.: The effect of incisional infiltration of bupivacaine hydrochloride upon pulmonary functions, atelectasis and narcotic need following elective cholecystectomy. Surg Gynecol Obstet 1983; 157: 338-340.

8. Rees, S.: Current Controversies in Neurosurgery. Dis- 
connective neurosurgery: Multiple bilateral percutaneous rhizolysis (facet rhizotomy). WB Saunders Company, Philadelphia, Pennysylvania, USA, 1976. pp: 80-88.

9. Shealy, N.: Technique for percutaneous spinal facet rhizotomy. Radionics, Procedure technique series, Burlington, MA, USA, 1972. pp: 1-12.

10. Wiese, M., Kramer, J., Bernsmann, K., Ernst, W.R.: The related outcome and complication rate in primary lumbar microscopic disc surgery depending on the surgeon's expe- rience: comparative studies. Spine J 2004; 4: 550-556.

Bademci, G.; Basar, H.; Sahin, S.; Ozcakir, S.; Anbarci, H.; Evliyaoglu, C.; Keskil, S.: Can facet joint infiltrative analgesia reduce postoperative pain in degenerative lumbar disc surgery? Neurocirugía 2008; 19: 45-49.

Corresponding adress: Gulsah Bademci, MD. Buketkent Mh. Iller Sitesi. 9/9 06530 Cayyolu. Ankara. Turkey. 